\title{
Waldenström type macroglobulinaemia in a Nigerian with rheumatoid arthritis
}

\author{
H. MCFARLANE AND C. NWOKOLO \\ From the Departments of Chemical Pathology and Medicine, University College Hospital, \\ University of Ibadan, Nigeria
}

SYNOPSIS Waldenström type macroglobulinaemia has been found in a Nigerian woman with rheumatoid arthritis and cryoglobulinaemia. Twenty-nine per cent. of the total serum proteins were macroglobulins, consisting of $27 \% 19 \mathrm{~S}$ and $2 \% 29 \mathrm{~S}$. Agglutination tests for rheumatoid arthritis were positive.

More than 200 cases bearing the classical description of Waldenström's macroglobulinaemia have been reported in the literature since Waldenström first described the syndrome in 1944 . Since then it has been found that a raised macroglobulin (IgM) content in the serum is a symptom of several other diseases. For instance, macroglobulinaemia has been reported in 14 different cases of myelomatosis (Adner, Wallenius, and Werner, 1960); in patients suffering from trypanosomiasis (Massayeff and Gombert, 1963), and Sandor, Charmot, and Vargues (1964) also reported raised amounts of IgM in Africans with various chronic infections; in the nephrotic syndrome, liver cirrhosis, collagen diseases, and rheumatoid arthritis (Burtin, 1964). Consequently Ritzmann, Thurm, Truax, and Levin (1960) grouped the macroglobulinaemias into the following three classes according to the concentration present in the blood: 1 physiological macroglobulinaemia where the IgM is rarely more than $5 \%$ of the total plasma protein; 2 secondary macroglobulinaemia, which included the neoplastic diseases, collagen diseases, and chronic infections where the IgM seldom exceeds $15 \%$ of the total protein; and, 3 , primary macroglobulinaemia in which the $\operatorname{IgM}$ is usually more than $15 \%$ of the total serum proteins.

Although it is well known that the rheumatoid factor is a macroglobulin of the $19 \mathrm{~S}$ class, only four known cases, one by Kunkel (1960), one by Sirridge (1960), and two by Gothoni, Wasastjerna, and Jeglinsky (1965) have been described in which the rheumatoid factor is associated with such a marked increase of macroglobulin as is usually only found in cases of Waldenström macroglobulinaemia. The present report is concerned with a case of rheumatoid Received for publication 2 June 1966. arthritis with Waldenström type macroglobulinaemia in a Nigerian woman, seen at the University Hospital, Ibadan, Western Nigeria.

\section{CASE REPORT}

A 27-year-old Yoruba woman was admitted to the University of Ibadan Hospital with swelling and pains in the wrists, elbows, and legs, as well as itching all over the body, for two months. Mild fever and headache were also present. On examination she was an ill-looking young woman with a wrinkled, pale skin. The temperature was $99^{\circ} \mathrm{F}$; blood pressure $140 / 90 \mathrm{~mm} . \mathrm{Hg}$, and the cardiovascular and respiratory systems were normal. The liver was smooth, and enlarged to four fingerbreadths below the costal margin, and the spleen was felt one fingerbreadth below the costal margin. There was some soft tissue swelling over both wrists and over the elbow joints. Pain and limitation of movement were also present on passive flexion and extension of the affected joints. There was a trace of protein in the urine, but no abnormality on microscopy. The central nervous system was normal, and there were no abnormally enlarged lymph nodes. A clinical diagnosis of rheumatoid arthritis was made.

\section{LABORATORY INVESTIGATIONS}

haematology Hb $49 \%$; P.C.V. $23 \%$, M.C.H. $35 \%$, leucocytes $7,300 \mathrm{~mm}^{3}$, reticulocytes $3.4 \%$. The differential count showed neutrophils $52 \%$, eosinophils $11 \%$, lymphocytes $35 \%$, monocytes $2 \%$, anisocytosis $(t)$, polychromasis $(++)$, and target cells $(+)$. There was marked rouleaux formation of the red cells. She belonged to group ORh $(+)$. Prothrombin time was 55 seconds (control 45 seconds), and the $\mathrm{Hb}$ genotype was AS. There were no trypanosomes or malarial parasites in the blood.

Bone marrow biopsy showed transitional megaloblastic erythropoesis, excess of plasma cells and small lymphocytes with some microfilaria. No L.E. cells were 
found on repeated examination. Liver biopsy was postponed because of a prolonged prothrombin time. Bone marrow culture showed excess of eosinophils and many normal plasma cells. Radiographs of the long and flat bones showed no abnormality except for slight generalized osteoporosis.

The latex test for rheumatoid factor was positive and the Rose-Waaler test titre was 1:32. The blood urea was $23 \mathrm{mg} . \%$ and serum calcium $8.2 \mathrm{mg}$. \%. The plasma bilirubin, alkaline phosphatase, transaminases, and bromsulphatein tests were normal. Thymol turbidity was 10 units and thymol flocculation test $(+++)$. Electrophoresis of the concentrated urine on both cellulose acetate and in agar gel produced only a single band of protein in the gamma region, probably a Bence Jones protein (Osserman and Takatsuki, 1963), which on immunoelectrophoresis gave a precipitin line with both IgG and IgA antisera but no line of precipitin was observed with IgM antisera.

SERUM PROTEIN ANALYSIS At $7^{\circ} \mathrm{C}$. the serum became very turbid with a flocculent precipitate which disappeared on warming to $37^{\circ} \mathrm{C}$, , indicating the presence of a cryoglobulin. The Sia test was strongly positive. Total protein was $11.1 \mathrm{~g} . \%$ and electrophoresis on cellulose acetate showed a very marked increase of protein in the gamma globulin region. There appeared to be a narrowish band (probably the IgM) immediately behind the point of application but this was blurred by a broader trailing diffuse zone. Spontaneous precipitation of part of the IgM was observed at the point of application on the cellulose acetate membrane. Figure 1 shows the scanned diagram for the electrophoresis strip, and the calculated values for the various serum proteins are: albumin $2.12 \mathrm{~g} . / 100 \mathrm{ml}$.; alpha ${ }_{1} 0.55 \mathrm{~g} . / 100 \mathrm{ml}$., alpha ${ }_{2} 0.64 \mathrm{~g} . / 100$ $\mathrm{ml}$; beta $1.65 \mathrm{~g} . / 100 \mathrm{ml}$; and gamma $6.15 \mathrm{~g} . / 100 \mathrm{ml}$. The marked increase of the gamma globulins here is quite obvious.

IMMUNOCHEMISTRY Quantitation of the immunoglobulins was by the method described in detail by Soothill (1962) and adapted from the method of Gell (1957). Antisera were obtained from various sources. Purified gamma globulin from both the Connaught Laboratory for Medical Research, Toronto, Canada, and from the Lister Institute Blood Products Laboratory were used as

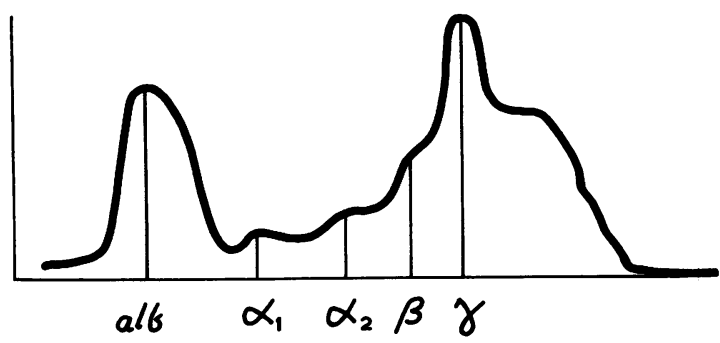

FIG. 1. Scanned diagram obtained from the electropherogram of the patient's serum. The sharp peak and the broad base of the gamma globulins are easily seen. standards in the estimation of IgG. Immunoglobulin? standards were also obtained from Hyland Laboratory $\vec{F}$ California. The results were: IgA $4.00 \mathrm{mg} . / \mathrm{ml}$.; IgC? $40.0 \mathrm{mg} . / \mathrm{ml}$.; IgM $76.80 \mathrm{mg}$. $/ \mathrm{ml}$.

IMMUNOELECTROPHORESIS Using the technique described by Grabar and Williams (1953) immunoelectrophoresis confirmed the quantitative results, and showed a markeof increase of the IgA, IgG, and IgM precipitin lines Figure 2 shows that a significant part of the IgM globulip was spontaneously precipitated in the agar in the cathoderegion close to the antigen reservoir, and also that the IgM precipitin line is longer and more intense than tha? of the normal serum with a typical double curvature? characteristic of macroglobulinaemia (Hassig, Gugler: and Scheidegger, 1964). The IgA and IgG precipitin lines are also stronger than the normal.

ULTRACENTRIFUgation This showed values for $29 \mathrm{~S}$ to be $2 \%$, for $19 \mathrm{~S} 27 \%$, for $7 \mathrm{~S} 28 \%$, and for $4.5 \mathrm{~S} 43 \%$ (Fig. 3).

STARCH GEL ELECTROPHORESIS Performed according to the method of Smithies (1955) this showed that th macroglobulin did not migrate through the starch gel bu币 was deposited at the point of application and that there was a marked increase of the IgG band. Gel filtration of the serum on Sephadex G-200 showed considerably raised

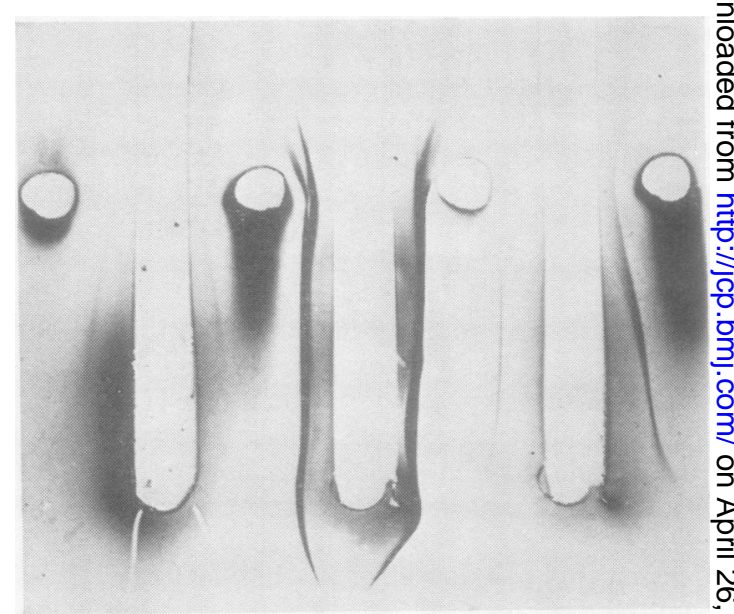

FIG. 2. Immunoelectrophoretic precipitin patterns pro๑ duced after the patient's serum and a normal serum weres electrophoresed in agar and reacted with antisera of the three immunoglobulins. The troughs contain from top t\$ bottom: anti-IgM, anti-IgG and anti-IgA. The patient's serum was electrophoresed in both the uppermost and third holes, whereas the normal serum was electrophoresed in the second and fourth holes from above downwards. The marked increase, the double curvature of the IgM pre cipitin line and the spontaneous precipitation of macro? globulin of the patient's serum just behind the point o. application are obvious. 


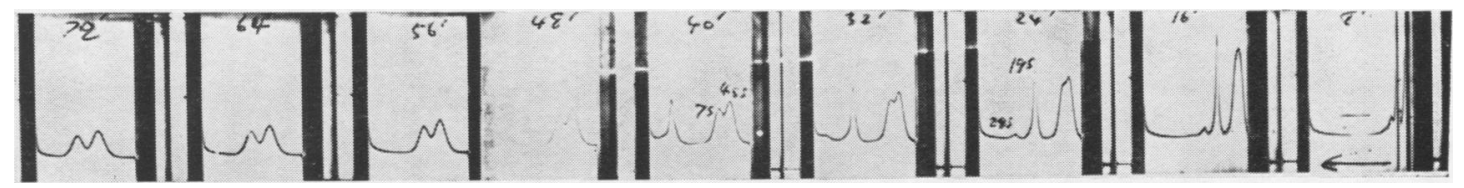

FIG. 3. Analytical ultracentrifuge patterns of the patient's serum. The exposure intervals in minutes and the different components, including the $19 S$ and $28 S$ are indicated.

$19 \mathrm{~S}$ and $7 \mathrm{~S}$ peaks when compared with normal serum run on the same column.

The final diagnosis was rheumatoid arthritis with macroglobulinaemia.

\section{COMMENT}

The markedly raised serum macroglobulin (IgM) level simulating that in Waldenström macroglobulinaemia, the raised levels of $\operatorname{IgG}$ and $\operatorname{IgA}$, the presence of cryoglobulinaemia, the excess of plasma cells, and small lymphocytes, and the single homogeneous electrophoretic band of protein in the urine of this patient with rheumatoid arthritis are very interesting and unusual findings.

As trypanosomiasis, which causes secondary macroglobulinaemia (Massayeff and Gombert, 1963), is endemic in parts of northern Nigeria, it ought to be emphasized that this disease is not found in Ibadan. Furthermore no trypanosomes were found in her blood and she showed none of the clinical stigmata of the disease. Microfilaria were found in the bone marrow but as far as we are aware this seems to be quite unrelated to the macroglobulinaemia.

We wish to thank Dr. Curt Wasastjerna, Central Hospital, Vasa, Finland, for the latex fixation and Rose-Waaler tests, Dr. John Soothill, of the Department of Experimental Pathology, University of Birmingham, for a gift of some of the antisera used in this work, Dr. Dennis Stanworth of the same address for kindly performing the ultracentrifugal studies, and Dr. Ivan Riha, of the Institute of Microbiology, Prague, W.H.O. visiting professor, for a gift of immunoglobulin antisera.

\section{REFERENCES}

Adner, P. L., Wallenius, G., and Werner, I. (1960). Acta med. scand., $168,431$.

Burtin, P. (1964). In Immuno-electrophoretic Analysis, edited by P. Grabar and P. Burtin, p. 186. Elsevier, Amsterdam.

Gell, P. G. H. (1957). J. clin. Path., 10, 67.

Gothoni, G., Wasastjerna, C., and Jeglinsky, B. (1965). Acta med. scand., 177, 263.

Grabar, P., and Williams, C. A. (1953). Biochim. biophys. Acta (Amst.), 10, 193.

Hassig, A., Gugler, E., and Scheidegger, J. J. (1964). In Immunoelectrophoretic Analysis, edited by P. Grabar and P. Burtin. Elsevier, Amsterdam.

Kunkel, H. G. (1960). In Plasma Proteins, edited by F. W. Putnam, vol. 1, p. 279. Academic Press, New York.

Massayeff, R., and Gombert, J. (1963). Protides of the Biological Fluids, 11 th Colloquium, edited by H. Peeters, p. 87. Elsevier, Amsterdam.

Osserman, E. F., and Takatsuki, K. (1963). Medicine (Baltimore), 42, 357.

Ritzmann, S. E., Thurm, R. H., Truax, W. E., and Levin, W. C. (1960). Arch. intern. Med., 105, 939.

Sandor, G., Charmot, G., and Vargues, R. (1964). Presse méd., 72, 1353.

Sirridge, M. S. (1960). Ann. intern. Med., 53, 380.

Smithies, O. (1955). Biochem. J., 61, 629.

Soothill, J. F. (1962). J. Lab. clin. Med, 59, 859.

Waldenström, J. (1944). Acta med. scand., 117, 216. 